\title{
IMPLEMENTATION OF TAX REGULATIONS \\ ON INTERNET-BASED BUSINESS ACTIVITY CASE STUDY: GOOGLE'S TAX AVOIDANCE IN INDONESIA
}

\author{
Indah Susanti \\ Faculty of Economic and Business \\ Universitas Indonesia \\ Jakarta \\ indahsusanti.daryono@gmail.com
}

\author{
Laode Arahman Nasir \\ Faculty of Economic and Business \\ Universitas Indonesia \\ Jakarta \\ laodearahman@gmail.com
}

\author{
Vera Partiana Sukardianti \\ Faculty of Economic and Business \\ Universitas Indonesia \\ Jakarta \\ verapartianasukardianti@gmail.com
}

\begin{abstract}
To align with global and digital economic growth, businesses must be able to change competitive strategies and business models to keep them relevant to on-going developments. This also requires changes in government regulations, especially tax regulations in order to support business development. Google as a company providing Internet-based services and products, located in Singapore as regional office, conducts its business in Indonesia by utilizing tax treaty between Indonesia and Singapore in its tax planning scheme aimed at avoiding taxation. In Indonesia, Google only has a representative office that does not record revenues and profits derived from activities in the country. This study aims to first find out why Google is not willing to pay the income or profits derived from business activities in Indonesia, Second knowing what should be done by the government of Indonesia to Google to pay tax to the government of Indonesia. The research method used is normative juridical. Based on the results of the study, the existing tax regulation cannot support new business model that is
\end{abstract}

internet based business model. This cause the tax liability paid in Indonesia is inconsistent with revenue derived by Google from Indonesia. It is required significant changes on tax regulations that can be applied in internet-based business model. However, this application presents several obstacles, so the Indonesian government can learn from countries, including Britain, India and Australia in applying this tax regulation.

Keywords: Tax Regulation, Internet-based Business, Tax Avoidance

\section{BACKGROUND}

The phenomenon of internet-based business is undeniably a trend that characterizes business activities in both developed and developing countries. New concepts have evolved as the advancement of information technology and new business paradigms is regarded as the key to success of companies in the information age and the future. Advances in technology, computers and telecommunications support the development of Internet technology. 
The use of the internet in business is changing from functionality as a tool for electronic information exchange into a tool for business strategy applications, such as: marketing, sales, and customer service. Internet marketing has penetrated obstacles, national boundaries, and without standard rules. While conventional marketing, goods flow in large parties, through seaports, containers, distributors, guarantee institutions, importers, and bank institutions. Conventional marketing is more involved than marketing over the internet. Marketing on the internet is the same as direct marketing, where the consumer deals directly with the seller, even though the seller is abroad.

The use of the internet has experienced tremendous growth in the business field especially in large-scale enterprises. Since the discovery of internet technology in the 1990s its use is widespread because it is seen to provide enormous benefits for the smooth process of business activities. Seeing the fact, the application of internetbased technology is one important factor to support the success of a product of a company. To accelerate and increase sales quickly then by looking at the development of information technology is rapidly, we can utilize an on-line service in the form of e-commerce.

Under offline world, the sales system of customers used by the company is only written and manual, which often tend to mislead. With the services of internetbased business that can be quickly enjoyed by customers and companies themselves then all the services desired by customers can be immediately followed up with as soon as possible, so that the company will be able to provide the best service and the fastest for the customers. Therefore, with the utilization and use of internet technology is expected to provide great benefits to the competitive business world. Companies that are able to compete in the competition is a company that is able to implement technology and information into the company.

The increasing number of internet users impact on the increasing turnover of electronic commerce will cause some problems in the field of finance, one of which is tax. The existence of e-commerce with no geographical boundaries of course also raises the question of how the tax law is anticipating the income from internetbased transaction. Without proper taxation regulation of internet-based transactions, the potential for tax revenue on internetbased transactions can be lost.

Tax is one of the largest sources of state revenues. The country's largest revenue should continue to be optimally upgraded so that the country's growth rate and development implementation can work well. Thus, it is expected taxpayer compliance in carrying out its tax obligations voluntarily in accordance with applicable tax laws. Non-compliance with taxpayers may potentially avoid tax evasion.

Tax avoidance strategy is one way permitted by law even though it is very unfavorable to the State because it does not provide income for APBN. So, in practice tax avoidance is used as exploiting limitation in tax law without violating existing tax laws. Because the tax is a burden for the company so the greater the tax burden paid by the company then it can reduce revenue received by the company. In order for revenue received by the company is not reduced then the company uses tax avoidance as a necessary strategy. The most common tax avoidance strategy is done by companies involving two countries, especially in companies engaged in internet-based business model.

Tax avoidance strategies stipulated in taxation laws aim to avoid double taxation. Here is one method of avoidance of double 
taxation for example Bilateral Taxation Method. The Bilateral Taxation Method in its tax calculation should consider the treaty of the two countries (tax treaty). Indonesia cannot easily establish the amount of tax owed by foreign residents or international bodies of the two countries that have entered into an agreement.

Google, as a internet-based company, conducts its business activities in Indonesia as a representative office but is domiciled in Singapore. Based on tax treaty Indonesia and Singapore, Google enjoys withholding tax rate $0 \%$ on its revenue derived from Indonesia and books its revenue under its Singapore entity as stated in its billing. While the Indonesian government suspects that Google diverts as its existing income in Indonesia to Singapore to reduce the tax burden. As widely known, Singapore is one of a tax haven country. The Indonesia tax office alleges Google Indonesia paid less than 0.1 percent of the total income and valueadded taxes it owed last year

\section{LITERATURE REVIEW}

\section{Tax Evasion}

Based on empirically stand point, tax is a burden that can reduce the purchasing power of society, especially companies. So, tax can be seen as unprofitable. Unprofitable things will trigger a person to avoid tax evasion or resistance. Sri Mulyani (2013) argues that tax evasion can be grouped into two, namely as follows:

- Passive Resistance

Passive tax resistance is caused by the obstacles that complicate the tax collector. This resistance is not done actively let alone aggressively by the taxpayers.

- Active Resistance

Active resistance includes the scope of all efforts and actions directly directed against the tax authorities in order to avoid taxation.
According to Bernard P. Heber in Nurmantu (2005: 151), the definition of tax avoidance is a taxpayer's effort in exploiting the opportunities (loopholes) that exist in the tax laws, so as to pay lower taxes. In addition, under international taxation, tax avoidance can be considered legal practice, but this is considered to provide harm to the government because it will reduce state revenues. In addition, Suandy (2001) argues that tax avoidance is a "tax affairs" engineering that remains within the framework of taxation provisions. The understanding of tax avoidance is legal practice but if it is not in accordance with the provisions of the tax law, it will be utilized by certain parties to pay lower taxes.

Companies can avoid taxes by channeling the results of their business to the tax heaven. This can be done with three media, namely: holding company, intermediary and subsidiary company. A holding company is an entity that holds great control in a company.

The second means of tax avoidance is the intermediary establishment. Intermediary establishment consists of 3 schemes. First, foreign investment (PMA) to Indonesia by utilizing tax heaven country. The scheme is done by opening the first, intermediary company in the state tax heaven then create a subsidiary in Indonesia. Second, the scheme occurs when a company in Indonesia, wants to expand its business and open a branch in Indonesia itself but want to take advantage of tax heaven. Third, investment from Indonesia to abroad by utilizing intermediary company. Subsidiary company or subsidiary is an entity that can be fully controlled by a parent company due to share ownership of most or more of the company.

Utilization of media used as tax avoidance facility to tax heaven country can use the following method: (1) transfer pricing, (2) 
treaty shopping, (3) thin capitalization, (4) controlled foreign company. Transfer pricing can occur either between two companies in the same group (intercompany pricing) or even between two divisions of a company within the same company. As a benchmark of fairness and business practice is the price given by a company to another company that does not have a special relationship. The pricing is not in accordance with the fair transaction price is used multinational companies to gain profit from the difference in fair price with the price of the special party transactions in the country Low tax rates or no taxes at all. By using the transaction price with a related party, the Tax Base of the transaction will be much less than the Tax Base to the other party so that the tax paid is much lower.

Treaty shopping is done by a company to benefit from a tax treaty between two countries by creating an affiliated company in one of the countries where tax avoidance is practiced. The tax treaty rate applied by each country to another country would be the trigger for a treaty shopping. Countries with very low withholding taxes compared to their partner countries are Singapore, the Netherlands and Hong Kong.

\section{Tax Treaty}

A tax treaty is an agreement between two or more countries by dividing the right to impose a tax on income derived from a state sourced by a resident or resident of another country. The purpose of this tax treaty is to avoid the imposition of double taxation and various tax evasion efforts arising from transactions between the two countries.

One of the tax treaties that will be discussed is the Indonesian tax treaty with Singapore which was signed on May 8, 1990. The avoidance of double taxation on the tax object is as follows:

- Immovable property, income from immovable property under Indonesian-
Singapore tax treaty is taxable only from the country in which the immovable property is situated even though the owner of the immovable object is not a national of that State.

- The operating profit earned by a business entity in a country under this agreement may only be imposed by the country of which the enterprise is domiciled, but if the enterprise carries on business in the form of a permanent establishment in the other Contracting State, it may be taxed by the State concerned.

- Aircraft and shipping, for aircraft business and shipping taxation is different. The aircraft is taxable only to the country where the aircraft is from, while for the vessel during the voyage in the sea of the other country then the other country imposes a tax by deducting $50 \%$ which thereafter becomes the object of tax of the ship's originating state.

- Companies which have privileges, in the case of privileged companies because the function of this enterprise is to participate in the management, supervision and capital participation of the enterprise of the other State may be liable for any additional profits.

- Dividend, the taxation of dividends of a company which is domiciled in one country in the agreement if such dividends are granted to a national of one party, shall be taxable according to the tax law of that citizen. As for dividends whose shareholders are companies then the country where the place of domicile of the company may impose tax with the following provisions:

$>10 \%$ of the gross amount of the dividends, if the company has a $25 \%$ interest in the company.

$>15 \%$ of gross amount in any other case.

The exception to this agreement is that as long as the Singapore government does not 
regulate the additional dividend tax, the dividend earned by an Indonesian business entity from a Singapore enterprise is not taxable.

- Interest, for interest paid by a company domiciled in one of the countries in the treaty to not one of the nationals. The Agreement is subject to the tax of that citizen. For the collection of such taxes by being limited to (a) bonds, bonds, and other bonds; And (b) Loans, warranties or guarantees. State where a business entity is domiciled may impose a maximum of $10 \%$ tax. Other exceptions of interest are not taxable in respect of Indonesian or Singapore government affairs.

- Royalties, paid from one country to a citizen of the other country are taxed from a citizen / entity of another country, but the country of origin of the royalty may levy a maximum tax of $15 \%$ of the gross amount of the royalties.

- Independent employment, defined as professional services and other services. The tax imposed on such independent employment is derived, except within 90 days in the 12 months that such independent employment opens up services in the other country then the State may collect taxes.

- Employment in the employment relationship, in the form of salaries, wages or remuneration derived from one of the countries shall be taxed from the country in which the citizen is originated, unless the national has settled in the country for 183 days.

- The remuneration of directors, who work for a company not originating from the director's nationality against the benefits, is taxed as the enterprise is derived. In that case is the country referred to in this agreement.

- Public figures and athletes, public figure activities or athletes conducted in a country under this agreement are subject to tax based on the place of such activity but the tax is not levied if the funds for such activities come from the government.

- Pensioners, for pension funds obtained from work of a Contracting State in the treaty shall be taxable on the basis of the origin of the enterprise.

- Government officials, in the case of remuneration other than government pension funds will be taxed according to the law of the officer who issued the tax.

- Teachers and researchers, teachers and researchers who stay for no more than 2 years to teach and research will be exempt from tax. This provision shall not apply if the activities are performed for the benefit of certain persons or persons.

- Student and other participant ie Student, an employer or technician, an apprentice, a person receiving assistance or allowances for the purpose of study shall not be taxed on the payment of his life, all grants, allowances, rewards, and payments not more than 2,200 US dollars per year. Considering that all of the above are related to teaching and learning, research, and training activities.

- Unregulated earnings, the laws applicable in each Contracting State shall still apply to the tax on the taxation of income of the Contracting State in the Contracting State except as otherwise provided in this Agreement.

However, tax treaty is not applicable for companies that act as virtual presence, one example is Google. So, the shortcomings of these rules are used by Google to structure its tax management by not setting up a permanent establishment in Indonesia and not paying the tax in accordance with revenue that is derived from Indonesia.

\section{DISCUSSION}

Google is a US company-based that is known as a search engine with its mission is to organize the world's information and make it universally accessible and useful. 
It was founded by Larry Page and Sergey Brin on 1998. For this over the past two decades, Google has grown tremendously from a search engine becoming the giant technology company and touching lives of millions of users around the world.

With over 70 offices in more in 50 countries, Google offers a wide range of services and products and its innovation subsequently becomes a part of daily life including Android phones, Google Maps, Google Earth, as well as in business with its mail, mobile devices and analytics solutions.

Google, under its parent company Alphabet Inc, now has a market value of $\$ 680$ billion, listed as a $2^{\text {nd }}$ the biggest internet companies worldwide, exceeding Amazon, Facebook and Alibaba. Its market value increasing significantly from $\$ 498$ billion in 2016. Google offer its products for free to the online users such as web search, email, content creation, content storage, content publishing and sharing, commerce, and hardware. Here are some of the Google products that are popular among the online users:

- Google Web Search.

- Gmail.

- Google Docs.

- Chrome browser.

- Android operating system for smartphones.

- Google Play.

- Youtube.

- Blogger.

- Google Wallet. .

- Consumer hardware products.

Google processes over 40,000 search queries every second on average, which translates to over 3.5 billion searches per day and 1.2 trillion searches per year worldwide. The chart below shows the number of searches per year throughout Google's history:

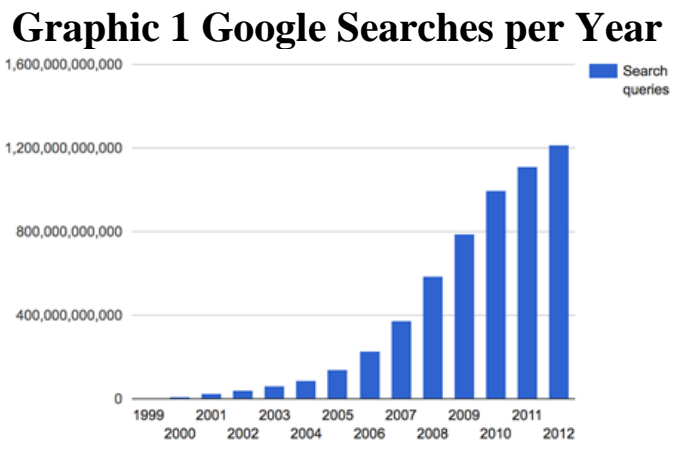

Source:

http://www.internetlivestats.com/googlesearch-statistics/

Based on this, Google enables marketers target the online users with its advertising products. Google generates revenue mainly by selling online advertising over its sites and its network member sites. Google Network is the network of third parties that use Google advertising programs to deliver relevant ads over their sites. Google generates a small percentage of revenue from its enterprise products.

Google offers following products to the advertisers:

- Google AdWords. It is an auctionbased advertising program that delivers ads based on user search queries..

- Google AdSense. It helps content owners monetize their content.

- DoubleClick Ad Exchange. It is a real-time auction marketplace for the trading of display ad space.

Below statistic shows Google's revenue worldwide from 2002 to 2016. In 2016, Google's revenue amounted to 89.5 billion US dollars. Google's revenue is largely made up by advertising revenue, which amounted to 67.39 billion US dollars in 2015. 


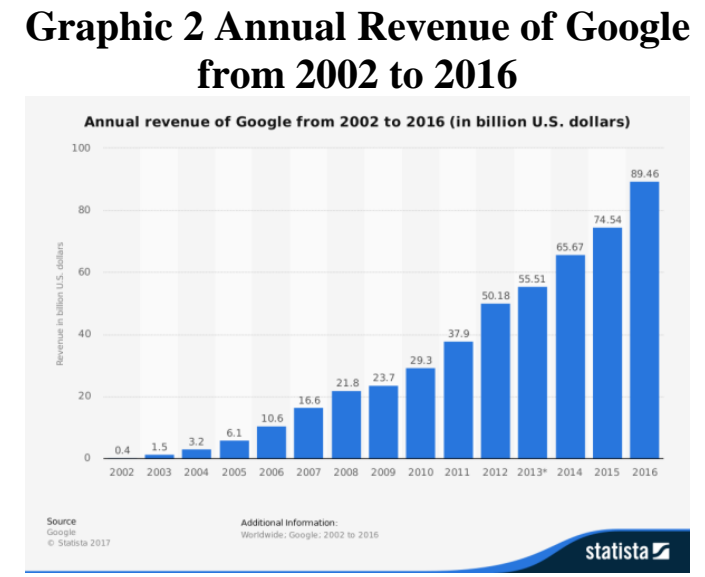

Source: https://www.statista.com

Below displays Google's advertising or ad revenue since 2001. In 2016, Google's ad revenue amounted to almost 79.4 billion US dollars or contributed $89 \%$ from total revenue. That year, advertising accounted for the majority percent of the online company's total revenues.

\section{Graphic 3 Advertising Revenue of Google from 2001 to 2016}

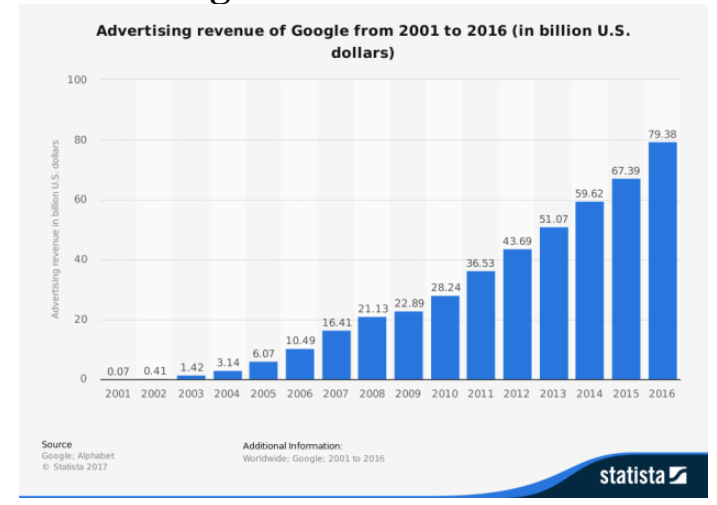

Source: https://www.statista.com

In Indonesia, number of internet users has been growing significantly year-over-year. With over 104 million internet users, Indonesia is one of the biggest online markets worldwide. It is estimated by 2022 number of internet user will grow to 139,54 million.

\section{Graphic 4 Number of Internet Users in Indonesia from 2015 to 2022}

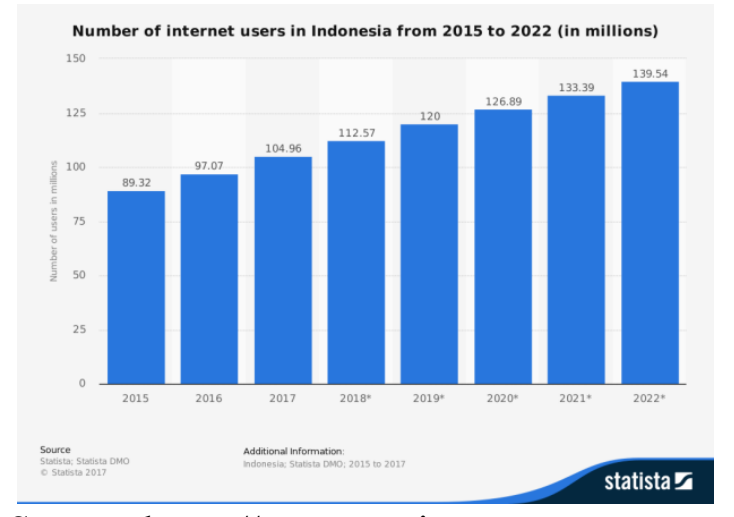

Source: https://www.statista.com

This huge market-size has attracted many investors, both local and foreign, to make investment in e-commerce businesses. For over the past of 7 years, e-commerce businesses have been grown tremendously in Indonesia. E-Commerce companies such as Tokopedia, Bukalapak, OLX, etc have been using Google to advertise their product and service and at the same time to monetize their content as one of revenue channel, that is advertising revenue. These business activities contribute substantial advertising revenue to Google.

Google runs its business in Indonesia from its regional office in Singapore, Google Pte Ltd. Google has office and also legal entity in Indonesia but there is no business operation, only representative office. This structure makes Google not liable to pay any taxes on revenue derived from Indonesia. In 2015, Google Pte Ltd book advertising total revenues of approximately US\$109.2 million from clients in Indonesia. There are 10 major Indonesian clients contribute approximately US\$60million or about $55 \%$ of Google Asia Pacific revenue. Google's tax management structure is using a loop-hole on tax treaty between countries, the practice of this tax avoidance is called a treaty shopping.

Many countries in worldwide including Indonesia has already taking a stand to fight Google to pay its tax obligation. 
Indonesia should immediately start introducing tax regulations to regulate the internet-based business model that can provide legal certainty both from the company side and tax officials.

\section{According to Indonesia Directorate} General Taxes, Google has not paid its tax obligation for the past five years. Google's tax debt in 2015 alone is estimated at Rp 5 trillion. This year, Indonesia government is managed to get Google to pay taxes in Indonesia for 2016 revenue, the amount is undisclosed, while the remaining past 5 years are still in process to complete.

In general, the current tax treaty has limitation on regulating companies that running its business through digital presence. With a business model like this, the approach taken must be fragmented because the business is expanding rapidly so that the rules should be made in such a way as to support the development of the business itself.

There are some challenges on implementing tax rule impose to internetbased company, those are, a high level of difficulty to identify the transactions, taxpayers are numerous and the number fluctuates because of the ease of entry or exit from this sector, cross border transactions, and all transactions recorded online that are not visible die so that requires expertise in the field of information technology to open or get the data.

Here are several approaches that can be referred that have been implemented in United Kingdom, India and Australia:

1. Diverted profits tax

In April 2015, The United Kingdom (UK) introduce the diverted profits tax (DPT) into its domectic tax law. The DPT has the declared objective of countering aggressive tax planning as used by many multinational enterprises to transfer profits from UK's jurisdiction by way of business structures that prevent the characterization of a permanent establishment (PE) within UK, either by the use of artificial transactions or of entities without economic substance. This rule applies to over the top (OTT) companies, like Google, which keeps a permanent company in another country whose income tax rate is below 80 percent of UK corporate tax rate. With the UK corporate tax rate of 20 percent, the OTT company that establishes a fixed-income company in a country with an income tax rate below 16 percent (80 percent of UK corporate tax) will be subject to a 25 percent real diverted profit tax. There are pros and cons on this approach because it is seen against tax treaty although it can be justified. Some of the cons, the levying of the DPT should be restricted to cases where UK can clearly demonstrate the artificiality of the legal structure used by a taxpayer, furthermore the state partner may challenge the breach of the tax treaty by UK arising as a result of the introduction of the DPT.

2. Multinational Anti Avoidance Rule Australia implemented this tax avoidance rule where if certain company structures are essentially only made for tax evasion then they cannot benefit the tax treaty. This is the Australian equivalent of the UK's diverted profits tax (DPT) and whilst the mechanics are very different, the Australian version shares the 'carrot and stick' approach of the DPT. The Australian approach is to add a new provision to Part IVA, Australia's general anti-avoidance rule (GAAR). By this form of amendment, there is no doubt Australia can override its existing double tax treaty commitments, at least at law, if not 
'politically'. The new provision (section 177DA) targets global groups that avoid an Australian taxable presence by undertaking significant activities in Australia with a direct connection to Australian sales, but where the sales revenue is booked overseas; and do so with a principal purpose of avoiding tax in Australia, or avoiding Australian tax and reducing a foreign tax liability.

The new section 177DA will apply where:

- There is a BEPS scheme

a) a foreign entity makes a supply to an Australian customer of the foreign entity

b) activities are undertaken in Australia directly in connection with the supply

c) some or all of those Australian activities are undertaken by an Australian entity or Australian permanent establishment (PE), either of which are associated with or commercially dependent upon the foreign entity

d) the foreign entity derives income from the supply

e) some or all of that income is not attributable to an Australian PE of the foreign entity.

- The principal purpose test is satisfied

- The foreign entity is a significant global entity

These measures will apply only to taxpayer groups with global revenues exceeding \$1bn.

3. Equalization Levy

The Indian government on February 29, 2016 introduced an equalization levy on online advertising revenue by non-resident e-commerce companies earned in India, which became effective on June 1, 2016. An equalization levy of $6 \%$ of the amount of consideration for specified services received or receivable by a nonresident not having a permanent establishment $(\mathrm{PE})$ in India, from a resident in India who carries out business or profession, or from a nonresident having a PE in India. Specified service is defined as follows:

a) Online advertisement

b) Any provision for digital advertising space or any facility/service for the purpose of online advertisement

c) Any other service which may be notified later by the central government

The equalization levy is aimed at taxing business-to-business (B2B) ecommerce transactions. Therefore, the scope of the levy may be expanded to cover a wider range of digital goods and services as time progresses. The levy would not be applicable to nonresident service providers having a $\mathrm{PE}$ in India, as they will be subject to regular PE-basis taxation. The levy is currently applicable only on B2B transactions, if the aggregate value of consideration in a year exceeds approximately US $\$ 1,500$.

To avoid double taxation of income which has been subject to an equalization levy, such income will be exempt in the hands of the nonresident under the Income Tax Act, 1961. However, one would need to evaluate the possibility of claiming a tax credit for such levy in the home country of the nonresident service provider. This is the first significant step taken by India to tax digital economy transactions.

Refer to above approaches, Equalization levy is the prominent approach to be implemented in Indonesia to tax multinational internet-based companies who derive revenue from Indonesia and do not have permanent establishment in 
Indonesia. Equalization levy has similar approach with the witholding tax in Indonesia. There are several approaches that must be done to implement equalization levy:

- Due to complexity, there should be cooperation in terms of providing and sharing information among government institution in Indonesia that consists of the Ministry of finance, Ministry of Communication \& Information, Ministry of Trade and Bank of Indonesia so that there is transparency as it has been described in the KUP article 35 that is when in the implementation of the provisions of the tax laws and regulations required information or evidence of banks, public accountants, notaries, tax consultants, administrative offices, and / or other third parties, who have a taxpayer relationship with tax audits, tax collection, or investigation of criminal acts in the field of taxation, upon written request from the tax director- the party is obliged to provide information or evidence received but this should not only relate to when the examination or error occurred so that the investigation due to criminal action .

- Income tax law no 36/2008 of article 2 and No SE - 04/PJ/2017 (4) regarding Foreign tax subject definition. It is necessary to amend in terms of the definition to include for foreign tax subject which derives income from Indonesia, this is to encounter cross-border transaction business model.

- Income tax law no 36/2008 of article 26 to amend minimum income earned amounting to USD 1,500 and subject to a tariff of $20 \%$ based on tariffs on Income Tax article 26 so that it can be applied for the following Google cases.
From tax administration stand point, it is simpler and more pragmatic to apply because Equalization levy is similar with withholding tax that have been applied refer to Indonesia Income tax law. Indonesia has to move fast on introducing new tax regulations for internet-based companies for transparency, fairness, and clarity.

\section{Reference}

Anggoro, Stefanus Tri. (2015). Analisis Pengaruh Perilaku Penghindaran Pajak Terhadap Nilai Perusahaan Dengan Transparansi Sebagai Variabel Moderating. Universitas Diponegoro. Semarang.

Chairysa, Ferin. (2012). Perbandingan Tax Treaty Indonesia - Singapura Dan Indonesia - Malaysia. Universitas Indonesia. Depok.

Desiana.(2012). Analisis Sistem Perpajakan Dan Hukum Di Negara Tax Haven Serta Kaitannya Dalam Praktik Penghindaran Pajak. Bina Nusantara University. Jakarta.

Dewi, Kristiana Nyoman Ni., \& Jati, I Ketut .(2014). Pengaruh Karakter Eksekutif, Karakteristik Perusahaan, Dan Dimensi Tata Kelola Perusahaan Yang Baik Pada Tax Avoidance Di Bursa Efek Indonesia. Jurnal Akuntansi Universitas Udayana. $249-260$.

EY. (2016, March 2). EY calls for India Propose Equalization Levy On Digital E-commerce Transaction In 2016 Budget.

Form Garage To The Googleplex. < https://www.google.com/intl/en/abou t/our-story/>.

"How Google Makes Money?" < https://revenuesandprofits.com/howgoogle-makes-money/>.

Internet Live Stats. < http://www.internetlivestats.com/goo gle-search-statistics/>. 
Irmawanti, Dewi. (2011). Pemanfaatan Ecommerce Dalam Dunia Bisnis. Jurnal ilmiah Orasi Bisnis.

Kusumawati, Hani. (2012, November 19). Prospek, Penerapan, Dan Kebijakan E-Business Di Indonesia. $<\mathrm{http}: / /$ blog.pasca.gunadar ma.ac.id/2012/11/19/prospekpenerapan-dan-kebijakan-e-businessdi-indonesia>.

Larastomo, Juoro., et al. (2016). Pengaruh Tata Kelola Perusahaan Dan Penghindaran Pajak Terhadap Manajemen Laba Pada Perusahaan Manufaktur Di Indonesia. Jurnal Bisnis dan Manajemen, 63-75.

Monica, Paul. (2016, May 12). Google Is Worth More Than Apple Again. CNN.

Mulyani,Sri \& Darminto.(2013).Pengaruh Karakteristik Perusahaan Koneksi Politik Dan Reformasi Perpajakan Terhadap Penghindaran Pajak.Surabaya: Universitas Brawidjaya.

Nurmantu, Safri. 2005. Pengantar Perpajakan Ed.3.Jakarta: Granit

PWC. (2016, June 6). PWC calls for India Introduces New Equalization Levy On Online Advertising Revenue.

Septarini, Nisa. (2012). Regulasi Dan Praktik Transfer Pricing Di Indonesia dan Negara Maju. Journal of Universitas Negeri Surabaya. Surabaya, Indonesia.
Santos, Ramon Tanazela(2016,July). The United Kingdom's Diverterd Profits Tax and Tax Treaties: An Evaluation.

Suandy, Erly. (2001). Perencanaan Pajak: Salemba Empat.

Suroyo,Gayatri \& Eveline Danubrata.(2016, September 20). Google Is Facing a \$ 400 Milion Tax Billion.

The Statistics Portal. <https://www.statista.com/statistics/ $>$

The World's Biggest Public Companies.

Forbes

<https://www.forbes.com/global200 0/list/\#tab:overall>

Tjaya, Eric. (2017). Analysis Of Income Tax On Tax Treaty Between Indonesia And Singapore Related To Indonesia Tax Amnesty Program 2016. Universitas Parahyangan, Bandung, Indonesia.

Utomo, Eviera Maharani. (2012). Transaksi E-commerce Sebagai Potensi Penerimaan Pajak Di Indonesia. Jurnal Universitas Negeri Surabaya.

Wahyudi, Dudi. (2015). Analisis Empiris Pengaruh Aktivitas Corporate Responsibility (CSR) Terhadap Penghindaran Pajak Di Indonesia. Jurnal Lingkar Widyaiswara. p0517. 